\title{
DRIE VROË̈ AFRIKAANSE ROLPRENTE (1938-1949) AS UITDRUKKING VAN DIE SOSIALE GEWETE VAN DIE AFRIKANER
}

\author{
Antoinique van Staden en Karina Sevenhuysen \\ Departement Historiese en Erfenisstudies, Universiteit van Pretoria, \\ Pretoria 0002
}

\section{Three early Afrikaans films (1938-1949) as expression of the social conscience of the Afrikaner}

This article investigates the origin and early development of the Afrikaans film industry and focusses especially on how certain contemporary ideologies, which were portrayed in the films, formed the basis of the social conscience of the Afrikaner.

Three films - Die Bou van 'n Nasie (1938), Simon Beyers (1947) en Kom saam vanaand (1949) - which were produced during these early years, were watched in an attempt to identify the charactertistics of the social conscience of the Afrikaner, using the explanation thereof by C.C. Nepgen. The characteristics that were looked at were religiousness, conservatism, worthiness, rural realism and cunning. The influence of prevailing ideologies, underlying these characteristics, was also identified.

In this article, the quality of the three films was not evaluated, but an investigation was done into what these films achieved or tried to achieve within the Afrikaner community. The focus is also on the significance of these films within the Afrikaner community. In conclusion, the value of these films and of research conducted on them, will also be indicated.

Key words: Afrikaans film industry, Afrikaner nationalism, conservatism, cunningness, hybridised Calvinism, paternalism, religiousness, rural realism, social conscience, worthiness.

Hierdie artikel ondersoek die onstaan en vroeë ontwikkeling van die Afrikaanse rolprentbedryf en fokus veral op hoe sekere tydgenootlike ideologieë wat in die rolprente uitgebeeld word, die grondslag van die Afrikaner se "sosiale gewete" gevorm het. 
Daar is na drie rolprente ${ }^{1}$ - Die Bou van 'n Nasie (1938), Simon Beyers (1947) en Kom saam vanaand (1949) - wat in hierdie vroeë tyd vervaardig is, gekyk in 'n poging om, aan die hand van C.C. Nepgen se uiteensetting, die eienskappe van die sosiale gewete van die Afrikaner te identifiseer. Die eienskappe waarna gekyk is, is godsdienssin, konserwatisme, waardigheidsbesef, landelike realisme en slimmigheid. Die invloed van heersende ideologieë onderliggend aan hierdie eienskappe is dan ook uitgewys.

Die gehalte van die rolprente word nie as sodanig behandel nie, maar 'n ondersoek word geloods na wat die rolprente binne die Afrikanergemeenskap bereik het of gepoog het om te bereik. Daar word ook gekonsentreer op wat die rolprente binne 'n Afrikanergemeenskap beteken het. Die waarde van die rolprente en van navorsing daaroor sal ten slotte aangedui word.

Sleutelwoorde: Afrikaanse rolprentbedryf, Afrikanernasionalisme, godsdienssin, konserwatisme, landelike realisme, paternalisme, slimmigheid, sosiale gewete, verbasterde Calvinisme, waardigheidsbesef.

\section{Agtergrond}

Van die vroegste tye af was drama en die toneelkuns maniere waardeur 'n samelewing hom kon uitdruk, terwyl vermaak terselfdertyd vir die massas aangebied kon word. Met die uitvinding van fotografie kon die vaslegging en uitbeelding van die toneelbedryf op 'n groot skaal deur mense bewonder word. Fotografie het later gelei tot bewegende beelde wat eers as stilprente en later as "talkies" bekendgestaan het. Die eerste rolprente het al teen die 1890's hulle verskyning in Suid-Afrika begin maak. Rolprente is tydens hierdie pioniersdae deur brokkies nuus en natuurtonele gekenmerk.

Die ontstaan van 'n Afrikaanse rolprentbedryf het teen die veertigerjare van die twintigste eeu vir die Afrikanervolk 'n noodsaaklikheid geword. Prominente figure betrokke by die bedryf het dit as 'n saak van erns beskou. Daar moes dringend 'n alternatief gevind word vir die "Amerikaanse gemors", wat op daardie tydstip in Suid-Afrika in Engels vertoon is. Dit het aan mense soos Joseph Albrecht en Pierre de Wet die geleentheid gebied om hulle hand aan Afrikaanse rolprente te waag.

Teen die 1940's was daar nog geen sprake van 'n eie finansieringsprogram vir die subsidiëring van Afrikaanse rolprente nie. Die feit dat die meeste akteurs geen

Dank word uitgespreek teenoor sowel die Nasionale Klank- en Filmargief wat die video's van die rolprente beskikbaar gestel het, as die Regering se Kommunikasiedepartement wat toestemming vir die bestudering van die rolprente verleen het. 
formele opleiding of selfs betaling vir hulle bydrae tot die bedryf ontvang het nie, het ' $n$ invloed gehad op die gehalte van die rolprente wat vertoon is. Akteurs is wel opgelei in drama en teaterproduksies en dit het aan Afrikaanse rolprente 'n dramatiese element verskaf. Ondanks dié struikelblokke het die bedryf wel groei getoon en sowat agttien titels is tot aan die einde van die veertigerjare vervaardig en aan gehore landwyd vertoon.

Vir die doel van hierdie artikel sal op die volgende drie rolprente gekonsentreer word:

Die Bou van 'n Nasie (1938). Dié rolprent volg die geskiedenis van die Afrikanervolk van die koms van Jan van Riebeeck na die Kaap tot en met Uniewording in 1910. Dit beeld al die groot gebeurtenisse in die volk se geskiedenis uit met groot klem op die Groot Trek.

Simon Beyers (1947). Dit vertel die verhaal van Simon Beyers, 'n voortuitstrewende boer aan die Kaap. Hy trou met 'n Hollandse meisie wat nie kan kinders hê nie, aangesien sy al te oud is. Aan die einde van die verhaal neem Simon en sy vrou, Simon se broerskind aan.

Kom saam vanaand (1949). Hierin word die verhaal verbeeld van 'n Afrikanermeisie wat in 'n ongeluk verlam word. 'n Plan word beraam om 'n konsert te hou om geld in te samel vir 'n operasie wat net in Amerika uitgevoer kan word. Die operasie is die meisie se enigste hoop om eendag weer te kan loop.

\section{Doelwit}

Daar word in hierdie studie nie as sodanig na die gehalte van die rolprente gekyk nie, maar 'n ondersoek word geloods na wat dié rolprente binne die Afrikanergemeenskap bereik het of gepoog het om te bereik. Daar word ook gefokus op wat hierdie rolprente binne 'n Afrikanergemeenskap beteken het.

Die studie is onderneem om aan te toon hoe bepaalde tydgenootlike ideologieë wat in die rolprente uitgebeeld is, die grondslag van die Afrikaner se "sosiale gewete" gevorm het. C.C. Nepgen ${ }^{2}$ het in 1938 die volgende eienskappe in die sosiale gewete van die Afrikaner geïdentifiseer: godsdienssin, konserwatisme, waardigheidsbesef, landelike realisme en slimmigheid.

Die outeurs probeer vasstel of die eienskappe van die sosiale gewete van die Afrikaner, soos dit deur Nepgen geïdentifiseer en geïnterpreteer is, in drie vroeë Afrikaanse rolprente aan Afrikaners as die aanvaarbare waardes en norme voorgehou

2 C.C. Nepgen, Die sosiale gewete van die Afrikaanssprekendes (Johannesburg, 1938). 
is. Die wyse waarop heersende ideologieë, ten grondslag van hierdie sosiale gewete, in die rolprente uitgebeeld is, word ook ondersoek. Die einddoel van die artikel is om die leser se oë te open vir die inhoudelike en simboliese waarde van die vroeë rolprente as tydgenootlike bron vir die uitbeelding van die sosiale gewete van die Afrikaner binne die betrokke tydgees.

\section{Bronnebespreking}

Verskeie navorsingsverslae ${ }^{3}$ oor die rolprentbedryf is reeds gepubliseer. Die oorgrote meerderheid verslae bevat net inligting oor die Europese, Amerikaanse en Asiatiese bedrywe. 'n Aantal publikasies ${ }^{4}$ oor die Suid-Afrikaanse rolprentbedryf bestaan wel, met die klem hoofsaaklik op die Engelse rolprente en produksiemaatskappye. Afrikaanse rolprente word hierin net vlugtig behandel. Party van die besprekings beslaan slegs een hoofstuk en bied aan die leser slegs 'n oorsig oor die gebeure rondom die ontstaan van 'n Afrikaanse rolprentbedryf. Hoewel die inligting onvolledig en onbevredigend is, kan verskeie waardevolle brokkies inligting uit hierdie bronne verkry word.

Vanweë die tekort aan publikasies oor Afrikaanse rolprente, is verskeie biografieë en dokumentêre programme ${ }^{5}$ wat oor individuele akteurs handel, as agtergrondsbronne gebruik. Verder is gebruik gemaak van tydskrif- en koerantartikels ${ }^{6}$ wat ter ere van "groot name" in die bedryf geskryf is.

'n Bron wat baie insig oor die beginjare van die Afrikaanse rolprentbedryf verskaf het, is in 1942 deur Hans Rompel as deel van 'n reeks gepubliseer. ${ }^{7}$ Rompel word as die voorste kenner van vroeë Afrikaanse rolprente beskou. Rompel beskou

3 T. Gutsche, The history and social significance of motion pictures in South Africa: 1895-1940 (Cape Town, 1972); R. Sklar, A world history of film (New York, 2002).

$4 \quad$ T. Gutsche, The history and social significance of motion pictures in South Africa (1972); A.I. le Roux \& L. Fourie, Filmverlede: Geskiedenis van die Suid-Afrikaanse speelfilm (Pretoria, 1982); H. Rompel, Die bioskoop in diens van die volk I \& II, Tweede Trek reeks (Bloemfontein, 1942); K.G. Tomaselli, Encountering modernity: Twentieth century South African cinemas (Pretoria, 2006); K.G. Tomaselli, The cinema of Apartheid: Race and class in South African film (Sandton, 1989).

5 A. Basson, Van kerslig tot kollig: Program oor die geskiedenis van die teater in Suid-Afrika, Episode XIII: Wena Naudé (1982); A. Basson, Van kerslig tot kollig: Program oor die geskiedenis van die teater in Suid-Afrika, Episode XVIII: Pierre de Wet (1982); M. Botha, Jans Rautenbach: dromer, baanbreker en akteur (Parklands, 2006); F.A. Theron, Die bydrae van Wena Naudé tot die Afrikaanse toneel en rolprent (Pretoria, 1991).

6 P. de Bruin, Al Debbo is nog nie dood nie ... hy is net semi-afgetree, Die Volksblad, 1997-29-11; J. Goosen, Ou flieke uit die kelder opgediep, Die Oggendblad, 1974-07-29; J.B. Willers, Eerste Afrikaanse klankprente, Die Brandwag, 1946-09-27.

7 H. Rompel, Die bioskoop in diens van die volk I \& II (1942). 
die rolprentbedryf as 'n middel waardeur die waardes van die volk weergegee kan word. Volgens hom kan rolprente ook aangewend word om aan die bevolking die aanvaarbare waardes en norme te openbaar, die sogenaamde "sosiale gewete". Dié bron is subjektief van aard, maar sodra dit saam met ander bronne uit die tydperk ondersoek word, word dit ' $n$ uitstekende bron vir 'n begrip van wat in hierdie tydperk in sowel die Afrikanergemeenskap, as die ontwikkeling van die rolprentbedryf aan die gang was. Hy het ook in verskeie tydskrifartikels oor die rolprentwese geskryf. ${ }^{8}$

Hoewel Rompel se geskrifte waardevolle bronne is, moet dit krities bejeën word. In sy bronne kom dit sterk na vore dat hy nie ten gunste is van rolprente wat uit die Verenigde State van Amerika na Suid-Afrika ingevoer is nie. Rompel lewer kommentaar oor die rolprentbedrywe wat voor die Tweede Wêreldoorlog in lande soos Duitsland, Rusland en Frankryk gefloreer het. Dié bron is ook uitgegee drie jaar voordat die oorlog beëindig is en dit kon dalk sy gunstige gevoel teenoor die Duitse bedryf aangehelp het. ${ }^{9}$

In enige bespreking wat oor rolprente handel, is dit nodig dat gekyk word na die simboliek en die ideologieë wat as grondslag vir die rolprente dien. Vir die doel van die studie sal meer klem op die prominente ideologieë en die simboliek gelê word as wat aan die tegniese aspekte aandag gegee gaan word. Daar sal aangetoon word hoe hierdie ideologieë en simboliek tot die vorming van 'n sosiale gewete vir die Afrikaner bygedra het. Vir die studie was Nepgen se publikasie ${ }^{10}$ van groot waarde. Die sosiale gewete van die Afrikaanssprekendes is, soos reeds genoem, in 1938 gepubliseer, die tyd waarin rolprente al hoe meer op Afrikanernasionalisme gekonsentreer het. Dit is gebruik om te verstaan wat 'n sosiale gewete is en hoe die eienskappe wat met 'n sosiale gewete verband hou, in die rolprente deur prominente heersende ideologieë versterk is. Nepgen se boek was deurslaggewend in die definiëring van wat die Afrikaner se sosiale gewete teen 1938 omvat het.

\section{Metodologie}

Drie van die eerste Afrikaanse rolprente is as tydgenootlike kultuurhistoriese bronne gebruik in 'n poging om die tydgees beter te verstaan en begrip te verkry vir die heersende waardes en norme onder Afrikaners. Die rolprente is op twee vlakke

\footnotetext{
8 H. Rompel, “Talkies”: Die bioskoop neem 'n misstap I, Die Huisgenoot, 1929-08-30; H. Rompel, "Talkies": Die bioskoop neem 'n misstap II, Die Huisgenoot, 1929-09-06; H. Rompel, Die woestynson het hulle laat sweet, Die Brandwag, 1946-10-04.

$9 \quad$ K.G.Tomaselli, Paradigms in South African cinema research: Modernity, the new Africa movement and beyond, Communication, 2008-06-01.

10 C.C. Nepgen, Die sosiale gewete van die Afrikaanssprekendes (1938).
} 
ondersoek, naamlik 'n eerste en 'n dieper betekenisvlak. Die rolprente is ondersoek oor die verhaal wat dit uitbeeld, asook oor die simboliese betekenis agter die dialoog en die ideologieë, onderliggend aan die onderskeie eienskappe van die sosiale gewete van die Afrikaner, wat in die rolprente uitgebeeld word.

\section{Eienskappe van die sosiale gewete van die Afrikaner}

Volgens C.C. Nepgen ${ }^{11}$ kan tussen 'n sosiale en 'n individuele gewete onderskei word. Die sosiale gewete van die groep berus daarop om 'n gemeenskaplike waardestelsel neer te lê wat aan die groep die aanvaarbare waardes en norme openbaar. Hy sê verder:

Die sosiale gewete staan ook in verband met die volksgewoontes en die wette van 'n land, maar moet hiervan onderskei word veral daarin dat dit slegs met die wesenlike etiese waardes te doen het. ${ }^{12}$

Nepgen het sy vertolking van die heersende sosiale gewete van die Afrikaner in 1938 geformuleer wat tydgewys met die begin van die Afrikaanse rolprentbedryf saamval. Die eienskappe van die sosiale gewete wat in die vroeë Afrikaanse rolprente teenwoordig is, herinner die Afrikaner daaraan dat om 'n "goeie Afrikaner" te wees, aan bepaalde vereistes voldoen moet word. Verskeie eienskappe het deel van die sosiale gewete gevorm. Later sal ook aangedui word dat heelwat heersende ideologieë in hierdie sosiale gewete vervat is.

Die eerste eienskap wat deel van hierdie sosiale gewete gevorm het, was 'n godsdienssin. Op daardie tydstip was die Afrikaner se sosiale gewete godsdienstig van aard. Die Afrikaner was Calvinisties by die beoefening van sy godsdiens. Die Bybel was die aanvaarbare riglyn waardeur die Afrikaner hom moes laat lei. Dit was ook die enigste riglyn vir sedelike en sosiale aangeleenthede. ${ }^{13}$ In die Afrikaanse rolprente kom hierdie godsdienssin na vore. In Die Bou van 'n Nasie word alle eer aan God gegee vir die vestiging van 'n nuwe volk aan die Suidpunt van Afrika. Die volk moet God dank omdat Hy hulle veilig tot hier gebring en elke dag beskerm het.

Die tweede eienskap wat deel van die sosiale gewete was, was konserwatisme. Die Afrikaner was oor die algemeen konserwatief in gebruike, tradisies, waardes en norme. Op nuwe gebruike wat ou tradisies ontwrig het, is neergesien en sodanige gebruike is krities bejeën. Die konserwatisme het ook oorgespoel in die tipe vermaak

\footnotetext{
11 C.C. Nepgen, Die sosiale gewete van die Afrikaanssprekendes (1938).

12 C.C. Nepgen, Die sosiale gewete van die Afrikaanssprekendes (1938), p. 43.

13 C.C. Nepgen, Die sosiale gewete van die Afrikaanssprekendes (1938), pp. 152-153.
} 
waarmee Afrikaners hulleself vereenselwig het. ${ }^{14}$ Sowel Simon Beyers as Kom saam vanaand, verseker dat die vermaak waarmee die Afrikaners hulle in die rolprente besig hou, die waardes van die volk weerspieël. Voorts word volksliedjies gesing en volkspele gedoen en dié aktiwiteite word as voorbeelde van goeie Afrikanervermaak voorgehou. Geen buitelandse vermaak moes geduld word nie.

Die sosiale gewete van die Afrikaner was in Nepgen se woorde aristokraties in die sin dat die Afrikaner aanvaar het dat hy 'n doel en roeping in die lewe het. Die Afrikaner moes dan ook die selfstandigheid en verantwoordelikheidsin openbaar om hierdie roeping te volvoer, ongeag wat dit behels het. ${ }^{15}$ Hierdie waardigheidsbesef word veral in die rolprent Die Bou van ' $n$ Nasie uitgebeeld. Die doel van die Afrikaner was om die onbekende binneland in te trek sodat God daar aan hulle 'n nuwe lewe kon wys. Dit was hulle doel om hierdie ongerepte, barbaarse binneland in 'n land tot eer en verheerliking van God te omskep.

Die volgende eienskap van die sosiale gewete van die Afrikaner was landelike realisme. Die Afrikaner het groot waarde geheg aan alle aspekte wat met 'n landelike uitsig op die lewe verband hou. Die Afrikaner was 'n boer en moes hom as sodanig in die beskawing handhaaf. Die stedelike kultuur moes liefs vermy word en daar moes ten alle koste pogings aangewend word om die landelike lewenstyl te bewaar. ${ }^{16}$ Hierdie ideaal word ook in die letterkunde van dié jare weerspieël. Simon Beyers is 'n voorbeeld van 'n vroeë Afrikaanse rolprent waarin die landelike aspek baie aandag geniet. Simon is 'n trotse en hooggeagte boer wat sy plaas bewerk. Sy broer Nicolaas wil net by die huis bly of jag en in die rolprent word subtiel op hom neergesien.

Die laaste eienskap wat die sosiale gewete van die Afrikaner bepaal het, word deur Nepgen as "slimmigheid" beskryf. Nepgen beskryf slimmigheid soos volg:

Die sosiale gewete van die Afrikaner vertoon 'n eienaardige vindingrykheid, 'n vernuftige plooibaarheid wat ons nie met onreg nie met die karakteristieke Afrikaanse woord, "slimmigheid", kan beskryf. . $^{17}$

Nepgen se "slimmigheid" is relatief vry van negatiewe konnotasies en verwys na vernuftigheid, na die vermoë om 'n probleem te ontrafel, die persone of kragte agter die probleem te uitoorlê, 'n plan te maak, en met oorspronklikheid die probeem te oorkom. Die uitdrukking “"n Boer maak 'n plan" is dalk die mees gepaste omskrywing binne die gegewe konteks.

\footnotetext{
14 C.C. Nepgen, Die sosiale gewete van die Afrikaanssprekendes (1938), pp. 154-155.

15 C.C. Nepgen, Die sosiale gewete van die Afrikaanssprekendes (1938), pp. 155-156.

16 C.C. Nepgen, Die sosiale gewete van die Afrikaanssprekendes (1938), pp. 158-159.

17 C.C. Nepgen, Die sosiale gewete van die Afrikaanssprekendes (1938), pp. 161-162.
} 
Dié eienskap word in die rolprent Kom saam vanaand waargeneem. Wanneer 'n Afrikanerdogter, met baie potensiaal, in 'n ongeluk verlam word, word 'n plan beraam om geld vir haar operasie in te samel. Afrikaners staan saam om 'n konsert te hou met die doel om vir die dogter 'n beter toekoms te kan gee.

\section{Konseptualisering}

Die rolprentbedryf maak gebruik van konsepte en terminologie wat eie aan die relatief moderne verskynsel is, en wat verdere verduideliking noodsaak. Belangrike konsepte in hierdie studie moet ook indringend verklaar word. Naas die term sosiale gewete wat reeds vroeër verduidelik is, word bepaalde terme en definisies gebruik wat ooreenkomstig die sosiale gewete van die Afrikaner verduidelik moet word.

Die eerste term is ideologie. Volgens Fatton is 'n ideologie drieledig van aard. Die eerste doel van ' $n$ ideologie is om aan individue te openbaar waaruit die samelewingsorde bestaan, ' $n$ identiteit aan hulle toe te skryf, en te verduidelik hoe hierdie identiteit in die konteks van 'n groter beeld figureer. Tweedens openbaar 'n ideologie aan individue moontlike optredes as aansporing om spesifieke ambisies en aspirasies te bereik. Laastens beskik 'n ideologie oor die vermoë om aan individue die verskil tussen reg en verkeerd, goed en kwaad, aan te toon. Dit lei daartoe dat alle fasette van 'n gemeenskap deur hierdie beginsels bepaal word. ${ }^{18}$

Liebenberg is weer van mening dat ' $n$ ideologie iets is waarin individue glo. Maar so eenvoudig is dit ook nie. 'n Ideologie op sigself is twyfelagtig en 'n vaste definisie kan nie noodwendig daaraan gekoppel word nie. Historici gebruik 'n ideologie om as 'n beskrywende instrument te dien in 'n poging om die huidige politiek en die verlede beter te verstaan. ${ }^{19}$ Vir die doel van hierdie bespreking sal van 'n kombinasie van hierdie twee onderskeie verklarings gebruik gemaak word. Daar sal na die ideologieë onder bespreking in die konteks van 'n maatstaf vir die samelewing, 'n sosiale gewete vir die Afrikaner, sowel as 'n beskrywende instrument verwys word.

Volgens Liebenberg sal die kenmerke van 'n ideologie ook hier in ag geneem moet word. 'n Ideologie sal gewoonlik 'n regverdigingselement bevat, waarvolgens die heersende orde en aanvaarbare optredes verklaar word of waarvolgens die heersende orde deur 'n geskikter een vervang moet word. Hierdie regverdigingselement verskaf ook aan die aanhangers van die ideologie 'n verklarende raamwerk waarvolgens verdere optredes bepaal word. Voorts bevat 'n ideologie 'n program van aksie.

\footnotetext{
18 R. Fatton, Black consciousness in South Africa: The dialectics of ideological resistance to white supremacy (Albany, 1986), pp. 40-41.

19 I. Liebenberg, Ideologie in konflik (Bramley, 1990), p. 15.
} 
Die program bied aan aanhangers praktiese riglyne vir die instandhouding van die heersende of 'n geskikter orde. Die volgende kenmerk van 'n ideologie spruit uit die eerste twee kenmerke. Indien albei hierdie kenmerke toegepas word, bring dit bepaalde politieke en sosio-ekonomiese instellings tot stand. Hierdie instellings kan as die ontstaan van 'n sosiale orde gesien word. Verder omvat 'n ideologie 'n bepaalde manier van dink waar teenstrydighede in die ideologie as uitdagings beskou word om dit te verbeter. ${ }^{20}$

Een van die belangrikste ideologieë wat in die rolprente teenwoordig is, is Afrikanernasionalisme. Volgens die Macmillan dictionary of historical terms ${ }^{21} \mathrm{kan}$ nasionalisme soos volg gedefinieer word:

The concept defies easy definition and takes diverse forms. Rather than being categorized by objective tests, it grows more from a subjective belief of common heritage that they [people] belong to a nation. This belief is often simply known as "national feeling" with the term nationalism being reserved for its more strident and exaggerated expression.

Vir hierdie studie word Afrikanernasionalisme omskryf as die bewustheid wat onder Afrikaners in die negentiende eeu ontstaan het dat hulle tot 'n groep behoort. Dié bewustheid het in die laat negentiende eeu die eerste keer as 'n teenvoeter vir Britse imperialisme posgevat. Dié nasionalisme het aan Afrikaners die geleentheid gebied om vir hulle 'n kultuur te skep wat op 'n gemeenskaplike waardestelsel, taal en geskiedenis gegrond was. ${ }^{22}$ Bewusmaking van die belangrikheid van die geskiedenis en kultuur het ook plaasgevind deur rolprente wat in die beginjare vir Afrikanergehore vervaardig is.

Die volgende ideologie waaraan aandag geskenk word, is kapitalisme. Volgens die Verklarende handwoordeboek van die Afrikaanse Taal, is kapitalisme ...

... 'n ekonomiese stelsel gegrond op privaatbesit en mededinging, met 'n minimum staatsbeheer. ${ }^{23}$

Kapitalisme is veral na die ontdekking van goud in 1886 aan die Witwatersrand as 'n negatiewe verskynsel beskou. Giliomee haal president M.T. Steyn van die Vrystaat soos volg aan:

20 I. Liebenberg, Ideologie in konflik (1990), pp. 14-15.

21 C. Cook, Macmillan dictionary of historical terms (London, 1989), p. 235.

22 J.P. Brits, Penguin concise dictionary of historical and political terms (1995), p. 7.

23 F.F. Odendal (reds.), Verklarende handwoordeboek van die Afrikaanse taal (HAT) (Johannesburg, 1965), p. 523. 
Kapitalisme het sy verskyning in Suid-Afrika gemaak en kapitaal, die vyand van die arbeid, het sy seekatpote om alle vorme van arbeid geslaan. ${ }^{24}$

Hierdie gevoel van onderdrukking deur die ekonomiese stelsel in Suid-Afrika het in van die eerste rolprente voorgekom.

Voorts word kolonialisme en imperialisme bespreek. Brits definieer kolonialisme soos volg:

European conquest and exploitation of territories in America, the East and Africa, starting about 1500. The term is associated with imperialism. ${ }^{25}$

In die Afrikaanse rolprente wat hier bespreek word, kom kolonialisme nie voor as uitbuiting van Afrikagebiede nie. Daar word eerder op 'n gevoel van anti-kolonialisme klem gelê. Probleme wat Suid-Afrika ondervind het in die tydperke waarin die rolprente afspeel, het plaasgevind as gevolg van die Anglo-Boereoorlog (1899-1902), deur Britse kolonialisme en imperialisme aangevuur. Die kombinasie van Britse imperialisme en kolonialisme, soos dit in die Anglo-Boereoorlog tot uiting gekom het, het die Afrikaner ontneem van 'n land waarvoor hy gewerk en geveg het. ${ }^{26}$

Nog 'n ideologie wat veral in die vroeë Afrikaanse rolprente teenwoordig is, is paternalisme. Pater beteken "vader". Dié ideologie het daarmee te make dat die leier van 'n groep soos 'n vader optree of regeer. Die ondergeskiktes word as kinders gesien en behandel. Die ideologie berus op twee aspekte. Die pater oefen beheer en dissipline oor sy onderdane uit, maar is ook vir die welsyn en sorg van die groep verantwoordelik, soos dit deur die oorheersende groep bepaal word. Die beginsel is ook deurgevoer na die regering van daardie tyd. Hoewel verantwoordelikheid vir die ondergeskiktes aanvaar word, is verwag dat die "kinders" gehoorsaam sal wees en hulle aan die goed-bedoelde regulasies sal onderwerp. ${ }^{27}$

'n Ideologie wat baie nou met die ideologie van paternalisme verband hou, is patriargisme. Dit bepaal dat iemand soos ' $n$ vader oor sy gesin, familie of stam regeer en was veral tiperend van negentiende eeuse families. ${ }^{28}$

Die beginsel van die vader as die hoof van die gesin, die leier en die besluitnemer, word deurgaans in die Afrikaanse rolprente waargeneem. Indien die seun nie dié rol by die vader kon oorneem nie, is dit as 'n skande vir die familienaam beskou.

\footnotetext{
24 H. Giliomee, Die Afrikaners: 'n Biografie (Kaapstad, 2004), p. 195.

25 J.P. Brits, Penguin concise dictionary of historical and political terms (1995), p. 50.

26 J. Albrecht, Die Bou van 'n Nasie (African Film Productions), 1938; J. Albrecht, Sarie Marais (African Film Productions), 1931.

27 F.F. Odendal (reds.), Verklarende handwoordeboek van die Afrikaanse taal (HAT) (1965), p. 825.

28 F.F. Odendal (reds.), Verklarende handwoordeboek van die Afrikaanse taal (HAT) (1965), p. 825.
} 
Die vader moes ook deur alle teenspoed sterk bly. Die rol van die vrou was een van ondersteuning, tuisteskepper en opvoeder. 'n Voorbeeld waarvolgens die beginsels sterk na vore kom, kom in die rolprent Simon Beyers voor. ${ }^{29}$ Die rol van die vader as die voorste leier word ook in die rolprent Die Bou van 'n Nasie gesien. ${ }^{30}$

'n Verdere ideologie wat in die rolprente teenwoordig is, is verbasterde Calvinisme. Voordat verbasterde Calvinisme bespreek word, moet die Calvinisme eers ontleed word. Die Calvinisme behels dat 'n sondige mens slegs gered kan word deur die genade en uitverkiesing deur God en die gevolglike volharding in die individu se geloof. Die Calvinisme berus op die beginsel van die absolute soewereiniteit van God. Die Calviniste aanvaar die hand wat God in hulle lewens het en bepaal hulle hele lewensgang volgens dié beginsel. Omdat almal as individue voor God staan, word hulle as gelyk geag. Daar is dan direkte verantwoordelikheid voor God. As op slegs een aspek van die Calvinisme klem gelê word, bestaan die gevaar dat die ideologie uit verband geruk kan word. Die Calvinisme is 'n geheel waarin sterk klem op die individu gelê word. Sodra die beklemtoning uit verband geruk word, kan iemand op grond van sy kerk-, familie- of volksverband van God se guns bewus word. ${ }^{31}$ So het die Afrikaners hulle as volk uitverkore voor God gesien - as Christen-Afrikaners - en nie as Afrikanerindividue nie. Hierdie verdraaide vertolking van en denkwyse oor die Calvinisme kan dan as verbasterde Calvinisme beskou word.

Verbasterde Calvinisme het as 'n regverdiging gedien vir die onderdrukking van die swart meerderheid van die Suid-Afrikaanse bevolking. Volgens verbasterde Calvinisme, was die Afrikanervolk uitverkore voor God, met die doel om die barbaarse volke in die binneland van Suid-Afrika van die beskawing en die ware God te leer. Volgens Giliomee ${ }^{32}$ het hierdie vorm van die Calvinisme weens die kultuurbotsing tussen swart en wit gedurende die agtiende eeu aan die oosgrens van die Kaap ontwikkel. Die Bou van 'n Nasie word uit dié perspektief aangebied. Verbasterde Calvinisme word in die rolprent as bydraende rede vir die Groot Trek aangedui. Die Groot Trek word uitgebeeld as 'n edel tog om aan die volke in die binneland 'n godsdiens te bring wat hulle kan red. Omdat hulle nie die ware God dien nie, moet hulle op die regte pad geplaas word. In die lig hiervan is die onderdrukking geregverdig van die mense wat in die binneland aangetref word. Die Afrikaner word terselfdertyd as 'n preutse, godvresende volk uitgebeeld.

\footnotetext{
29 P. de Wet, Simon Beyers (African Film Productions), 1946.

30 J. Albrecht, Die Bou van 'n Nasie (African Film Productions), 1938.

31 C.C. Nepgen, Die sosiale gewete van die Afrikaanssprekendes (1938), pp. 69-73; P.G. Nel (red.), Die kultuurontplooiing van die Afrikaner (Pretoria, 1979), pp. 51-58.

32 H. Giliomee, Die Afrikaners: 'n Biografie (2004), p. 28.
} 
Dit is vervolgens belangrik om te kyk na ideologieë wat veral in die negentiende en vroeë twintigste eeu internasionaal baie aandag geniet het. Sosiale Darwinisme ${ }^{33}$ was die ideologie wat veral gebruik is om swart onderdrukking te regverdig. Dit was:

...[a] school of thought which holds that the evolutionary process described in Darwinism is equally applicable to human society, influential before the First World War, arguing that only by constant moral, physical and economic development could a society maintain both internal cohesion and its defences against competing societies. ${ }^{34}$

Sosiale Darwinisme is gebruik om sowel die klassestelsel, blanke meerderwaardigheid, oppergesag en heerskappye, as 'n kompeterende kapitalistiese stelsel te regverdig. Onbelemmerde mededinging was in ooreenstemming met natuurlike seleksie. Rykdom is as 'n teken van sukses beskou. ${ }^{35}$ Party groepe armblankes sou ook volgens hierdie teorie as ondergeskik beskou word. Dit was om hierdie rede dat Afrikanerpolitici daarmee behep was om die armblankevraagstuk "op te los". Die rolprente wat aan die begin vervaardig is, beeld die Afrikanervolk as 'n verhewe, edele, en godverkore volk uit. Die Bou van 'n Nasie ${ }^{36}$ is die beste voorbeeld van 'n rolprent waar Sosiale Darwinisme, met sy klem op blanke meerderwaardigheid teenoor ander minderwaardige inheemse groepe, as 'n regverdiging vir 'n politieke agenda gebruik is.

Noudat na al die ideologieë onderliggend aan die sosiale gewete van die Afrikaner verwys is, sal die definisies bespreek word van twee konsepte wat problematies van aard mag wees. Die eerste konsep wat baie gebruik sal word, is dié van rolprent. 'n Tekort aan navorsing oor die Afrikaanse rolprentbedryf bestaan en as gevolg hiervan het probleme ontstaan met die definisie van die konsep rolprent as kenmerkend aan die genre. 'n Poging sal aangewend word om 'n aanvaarbare definisie vir hierdie konsep te formuleer, waartydens swaar op die Verklarende handwoordeboek van die Afrikaanse taa ${ }^{37}$ en verskeie artikels ${ }^{38}$ gesteun sal word. Daar word eerder na rolprente

\footnotetext{
H. Giliomee, Die Afrikaners: 'n Biografie (2004), p. 240.

C. Cook, Macmillan dictionary of historical terms (1989), p. 301.

C. Cook, Macmillan dictionary of historical terms (1989), p. 302.

J.Albrecht, Die Bou van 'n Nasie (African Film Productions), 1938.

F.F. Odendal (reds.), Verklarende handwoordeboek van die Afrikaanse taal (HAT) (1965).

38 H. Rompel, “Talkies": Die bioskoop neem 'n misstap I, Die Huisgenoot, 1929-08-30, pp. 37; 39, 43; J.M.H. Viljoen, Ons eie Filmbedryf?, Die Huisgenoot, 1944-05-05; J.B. Willers, Eerste Afrikaanse klankprente, Die Brandwag, 1946-09-27; E. Theron, Swak begrip van rolprentkuns, Die Brandwag, 1947-02-14.
} 
as na films verwys, omdat eersgenoemde begrip tydens die tydperk onder bespreking in gebruik was en laasgenoemde as 'n direkte oorname van die Engelse films beskou is. Die gebruik van rolprent verwoord die tydgees pasliker.

Die rolprente wat ontleed word, word deur Rompel as "talkies", spraakprente of klankprente beskryf. Die tipe rolprent wat voor die gebruik van klank vervaardig is, word in die algemeen in artikels as stilprente geklassifiseer. ${ }^{39}$ Die definisies van rolprent, soos deur die Verklarende handwoordeboek van die Afrikaanse taal aangedui word, is soos volg:

1. Strook, rol, bv. van sellulö̈de, gebruik vir fotografiese of kinematografiese opnames: film. 2. Voorstelling, weergawe wat opgeneem is op so 'n rol of rolle en vertoon word aan toeskouers. ${ }^{40}$

Die definisie hierbo omskryf presies wat 'n rolprent eintlik is, te wete 'n visuele voorstelling wat op 'n rolfilm opgeneem is en aan 'n gehoor gewys word. Vanuit hierdie konteks sal op die rolprente gekonsentreer word. Rolprente sal as 'n vermaaklikheidsmedium bespreek word. Verder sal ook op die betekenis van rolprente gelet word in terme van die ideologiese waardes en sosiale gewete wat hulle aan 'n gehoor kan openbaar.

Nog 'n konsep wat problematies was, is Afrikaner. Volgens die Penguin dictionary of historical and political terms is die definisie van 'n Afrikaner:

...white South Africans, mostly descendants of Dutch or Hugenot colonists, whose home language was to become Afrikaans. ${ }^{41}$

Die Verklarende handwoordeboek van die Afrikaanse taal definieer Afrikaners as 'n "persoon wat Afrikaans is deur geboorte of afstamming." ${ }^{2}$ In hierdie bespreking word van die begrip Afrikaner gebruik gemaak om na die groep mense te verwys wat Afrikaans gepraat het en deur Afrikanernasionalisme gedryf is om die rolprentbedryf te help ontwikkel. Hierdie groep het deur verbasterde Calvinisme 'n regverdiging gevind vir die temas wat in die rolprente gebruik is. Hulle is deur volkstrots gemotiveer. 'n Volk, - volgens Brits -

\footnotetext{
39 H. Rompel, “Talkies": Die bioskoop neem 'n misstap I, Die Huisgenoot, 1929-08-30, p. 37.

40 F.F. Odendal (reds.), Verklarende handwoordeboek van die Afrikaanse Taal (HAT) (1965), p. 910.

${ }_{41}$ J.P. Brits, Penguin concise dictionary of historical and political terms (1995), p. 8.

42 F.F. Odendal (reds.), Verklarende handwoordeboek van die Afrikaanse taal (HAT) (1965), p. 27.
} 
...usually refers to a body of people associated with a particular territory and who, in most cases, are of common descent, language and history and form a society under one government. ${ }^{43}$

Die Afrikaner bestaan dus uit 'n groep afkomstig uit dieselfde agtergrond, omstandighede en waardestelsel. Voorts word aanvaar dat die boodskappe oor aanvaarbare waardes en norme wat in die rolprente waargeneem is, verteenwoordigend was van wat die deursnee-Afrikaner van daardie tyd vas geglo en as hulle sosiale gewete ondersteun het.

Vervolgens sal die geselekteerde rolprente uit die vroeë fase van Afrikaanse rolprentontwikkeling, as uitdrukking van die sosiale gewete van die Afrikaner, ontleed word.

\section{Die Bou van 'n Nasie (1938)}

As 'n kultuurhistoriese bron is dié rolprent van onskatbare waarde. Dit beeld die gees van die 1938-eeufeesvieringe ter herdenking aan die Groot Trek baie goed uit en gee die kyker 'n idee van die Afrikanersamelewing en dié se sosiale gewete in hierdie tyd rondom die Tweede Wêreldoorlog (1939-1945). Die Bou van 'n Nasie is vir die eerste keer op 12 Desember 1938 in die Capitol Teater in Pretoria aan gehore vertoon. ${ }^{44}$

Die rolprent volg die geskiedenis van Suid-Afrika van die tyd toe Dias om die Kaap geseil het. Daar word meestal op die ontberinge van die Afrikanervolk klem gelê en amper veertig minute van die 120 minute vertoning handel oor die gebeure van die Groot Trek. Dit is 'n derde van die rolprent wat aan een gebeurtenis gewy is. Daar word wel erkenning aan swart leiers soos Shaka en Dingane verleen, maar hulle perspektief op die geskiedenis word nie weergegee nie. Die rolprent eindig met die verhaal van Uniewording in $1910 .^{45}$

Daar is gebruik gemaak van verskeie bekendes in die rolprentbedryf en grootskaalse navorsing is gedoen voordat die draaiboek geskryf is. Joseph Albrecht was die regisseur, maar vir die rolprent het hy ook hulp ingekry van H. Dalrymple, A.A. Pienaar (Sangiro) en S. Kirkland. Meer as honderd akteurs en 11000 mense is vir die massatonele gebruik..$^{46}$ Die Bou van 'n Nasie was op dié tydstip die enigste rolprent in Suid-Afrika wat op so 'n groot skaal vervaardig is. Die aanvanklike kosteberaming

\footnotetext{
43 J.P. Brits, Penguin concise dictionary of historical and political terms (1995), p. 166.

44 T. Gutsche, The role and significance of South African motion pictures: 1895-1940 (1972), p. 348.

45 J. Albrecht, Die Bou van 'n Nasie (African Film Productions), 1938.

46 A. I. le Roux \& L. Fourie, Filmverlede: Geskiedenis van die Suid-Afrikaanse speelfilm (1982), pp. 30-31.
} 
was $£ 35000$. Dit sou ook die eerste produksie in Suid-Afrika wees wat belangstelling van die staat gekry het. Voor Die Bou van 'n Nasie was rolprentvervaardiging in Suid-Afrika aan privaatmaatskappye oorgelaat. Maar in 1935 het Oswald Pirow, die Minister van Spoorweë en Hawens, geldelike steun vir die vervaardiging van die rolprent verleen. ${ }^{47}$

Die Bou van 'n Nasie sou aanvanklik vir buitelandse publisiteitsdoeleindes net in Engels vervaardig word, omdat gehore oorsee nie bekend sou wees met Afrikaans nie. Dié rolprent was veronderstel om aan die buiteland ' $n$ beeld van die goeie verhoudings tussen Engelssprekende Suid-Afrikaners en Afrikaners te gee. Nadat kosteberamings gedoen is en alle voorbereidings klaar was, het die vervaardigers besluit om ook 'n Afrikaanse weergawe te maak. Dit het dinge ingewikkelder gemaak. Die oorspronklike kosteberaming het verdubbel en kommer het bestaan oor watter Afrikaanse akteurs in staat sou wees om die hoofrolle te vertolk. ${ }^{48}$ Buitelandse beleggers het ook aandele in die rolprent gehad om met die uitgawes te help. Sodanige beleggers moes met die vervaardiging van die rolprent in ag geneem word. Die Engelse weergawe sou op die Engelssprekende inwoners van Suid-Afrika, asook op buitelandse gehore gemik wees, terwyl die Afrikaanse weergawe uitsluitlik vir Afrikaanse toeskouers vervaardig is. $^{49}$

Oorspronklik sou die rolprenttitel Salute to pioneers gewees het, maar toe is besluit om die titel na They Built a Nation -Die Bou van 'n Nasie te verander. Omdat 'n rolprent van so 'n omvang nie voorheen in Suid-Afrika vervaardig is nie, het dit oor die algemeen baie nuwe eise aan die bedryf gestel. Tegnici was nie gewoond aan grootskeepse verfilming nie, want in die voorafgaande jare was die meeste rolprentwerk in Suid-Afrika beperk tot dokumentêre verfilming of tot rolprente waarvan die vertoning nouliks 'n uur geduur het. Ook is gepoog om met Die Bou van 'n Nasie so histories korrek as moontlik te wees. Die feit dat die rolprent in sowel Afrikaans as Engels vervaardig sou word, het dié doelwit moeiliker gemaak. Die regisseur het ook probeer om al die tonele te skiet waar hulle werklik plaasgevind het. Maande voor die tyd is reeds na artefakte gesoek wat so na as moontlik aan die oorspronklikes was en in party tonele is selfs van die oorspronklike meubels gebruik gemaak.

47 T. Gutsche, The role and significance of South African motion pictures: 1895-1940 (1972), pp. 345346.

48 T. Gutsche, The role and significance of South African motion pictures: 1895-1940 (1972), p. 346.

49 A. I. le Roux \& L. Fourie, Filmverlede: Geskiedenis van die Suid-Afrikaanse speelfilm (1982), pp. 30-31. 
Voordat daar na die verskillende ideologieë en eienskappe rakende die sosiale gewete in die rolprent gekyk word, sal perskommentaar op Die Bou van 'n Nasie vlugtig in oënskou geneem word.

Ten spyte van hierdie skouspelagtige poging het die rolprent betreklik min aandag in die Suid-Afrikaanse pers geniet. Dit het slegs bestaan uit kort nuusbrokkies oor die rolprentspan wanneer hy in die onderskeie dele van die land aangekom het om tonele te skiet. Plaaslike belangstelling het wel bestaan, maar die gehore kon nog nie die totale omvang van die projek begryp nie. Vroeg in Februarie 1938 het party Afrikaanse koerante, soos Die Transvaler, African Film Productions gekritiseer en gesê dat die Engelse weergawe meer aandag as die Afrikaanse weergawe in die pers kry. Die pers se belangstelling het geleidelik gegroei totdat die rolprent vir die eerste keer aan die einde van 1938 vertoon is. ${ }^{50}$

Die Engelse pers het die rolprent skerp gekritiseer en die vervaardigers daarvan beskuldig dat hulle die reeds troebel verhoudinge tussen Afrikaans- en Engelssprekendes verder verswak het. Gutsche haal kritiek aan wat The Forum uitgespreek het:

... a series of numerous disjointed impressions ... there is too much occasion for interest and too little opportunity to nail it down. If Die Bou van 'n Nasie fails in its greater purpose of depicting the steady growth of a disunited country towards nationhood, it unqualifiedly succeeds in presenting certain aspects of that growth.... (the symbolical treatment of the Boer War is so banal as to make one wish it had been omitted). ${ }^{51}$

Die Afrikaanse pers was daarenteen gaande oor die rolprent en het net lof daarvoor gehad. Die Vaderland het dit "'n magtige faktor in ons nasiebou" genoem, terwyl Die Transvaler die volgende daaroor gesê het:

Niemand wat die rolprent aanvoelend aanskou, kan weggaan sonder 'n dieper indruk dat daardie selfde pad van Suid-Afrika wat ten dele so roerend uitgebeeld is, nog steeds voortloop na sy onverbiddelike einde: die vrye republiek van Suid-Afrika. ${ }^{52}$

Hierdie aanhalings dui baie duidelik die kommentaarverskil tussen die Afrikaanse en Engelse pers aan.

$50 \quad$ T. Gutsche, The role and significance of South African motion pictures: 1895-1940 (1972), pp. 346348.

51 T. Gutsche, The role and significance of South African motion pictures: 1895-1940 (1972), p. 348.

52 T. Gutsche, The role and significance of South African motion pictures: 1895-1940 (1972), pp. 348349 . 
Vir hierdie studie is slegs na die Afrikaanse weergawe gekyk en sal slegs op Die Bou van 'n Nasie gelet word. Die rolprent was uiters nasionalisties van aard en verskeie ideologieë het as grondslae vir die dialoog en draaiboek gedien.

Die eerste ideologie onderliggend aan die sosiale gewete van die Afrikaner, wat baie prominent in die rolprent na vore kom, is dié van Afrikanernasionalisme. Dit is immers die tema daarvan. Die rolprent beeld die geskiedenis van die Afrikanervolk uit, van die vroeë begin toe Dias om die Kaap die Goeie Hoop geseil het. Die Afrikaanse dialoog was ook nasionalisties van aard. Daar word baie prominent daarop gesinspeel hoe die Afrikanervolk hom aan die Suidpunt van Afrika moes vestig sodat hy vry kon wees en 'n nuwe kultuur en taal kon uitbou. 'n Derde van die rolprent word net aan die Groot Trek gewy, hoe die gebeure eindelik tot vryheid gelei het en hoe die verkreë vryheid later na die Anglo-Boereoorlog van hulle af weggestroop is. Uit die rolprent kry die toeskouer die gevoel dat min aandag aan die oorlog geskenk is. Dit het nie gebeur omdat die Afrikaners skaam was oor die oorlog nie, maar eerder omdat herinneringe aan daardie tyd steeds soveel pyn en smart veroorsaak het. ${ }^{53}$

Tomaselli is van mening dat Britse kolonialisme en imperialisme in Die Bou van 'n Nasie toenemend in konflik met Afrikanernasionalisme gekom het.

The struggle was waged at a dual level: a political one in which Afrikaners were fighting for ascendance over English-dominated capital; and an economic one where English-South African capital became subordinate to Afrikaner sociopolitical objectives... ${ }^{54}$

Op daardie tydstip het die wrywing tussen Afrikaans- en Engelssprekende blanke Suid-Afrikaners toegeneem. Die wrywing is nêrens sigbaarder as in die interpretasie van Die Bou van 'n Nasie nie.

Die wyse waarop die leiers van die Groot Trek uitgebeeld word, is ook 'n metode om Afrikanernasionalisme te bevorder. In die binneland ontmoet die trekkers vreemde volke en die leier (Piet Retief) moedig sy mense aan om soos goeie Christene met hulle nuwe bure vrede te maak - die godsdienssin en waardigheidsbesef van die sosiale gewete is hier beklemtoon. Retief neem 'n geselskap om met die magtige Zululeier, Dingane, te gaan onderhandel. Hulle vertroue word geskaad en die leiers word vermoor. Dit is gevolglik die plig van die ander trekkers om hulle op hierdie vyandige, barbaarse volke te wreek. Die Slag van Bloedrivier word met baie eerbetoon aangebied. Al die Afrikanerleiers word met baie respek uitgebeeld.

53 J. Albrecht, Die Bou van 'n Nasie (African Film Productions), 1938.

54 K.G. Tomaselli, Encountering modernity: Twentieth century South African cinemas (2006), p. 137. 
Die volgende ideologie wat baie aandag geniet, is paternalisme. In Die Bou van 'n Nasie is die man die leier wat besluit om 'n volk hier te vestig. Later is dit die sterk Afrikanermans wat weier om hulle kultuur en taal vir 'n Engelse juk prys te gee, en wat hulle volk die onbekende inlei. Dit vorm ook deel van die waardigheidsbesef van die Afrikaner. Hy is ook die pater wat sy kinders opvoed oor die belangrikheid van respek.

Die ideologie van patriargisme hou ook verband met paternalisme. Buiten vir die politieke aspek van die Afrikaners se lewens word ook op die sosiale aspek van gesinne in Die Bou van 'n Nasie klem gelê. Die vader lei sy gesin uit die verderflike Britse invloed na vryheid toe. Soos dit 'n goeie Afrikanervader betaam, word sy seuns opgevoed om die volgende leiers van die volk te wees. Die seuns moet soos dapper soldate die onbekende swart volke en later die Britse soldate aandurf.

Verbasterde Calvinisme speel ook 'n belangrike rol by die uitbeelding van die Afrikanergeskiedenis. In die rolprent word beklemtoon dat die Afrikaners wat met die Groot Trek na die binneland van Suid-Afrika uitgewyk het, ten alle koste die vrede met hulle nuwe bure wou bewaar. Hulle word deur barbaarse, vyandige mense gekonfronteer en ag dit hulle Godgegewe taak om dié mense te bekeer en hulle soos kinders (paternalisme) in die Westerse maniere en waardestelsel op te voed. Dit is God wat die voorlopers van die volk saam met Jan van Riebeeck in 1652 na hierdie "beloofde land" (Suid-Afrika) gelei het. Dit was God se wil dat dié uitverkore volk homself hier te lande moes vestig en sy kultuur en taal tot eer van God se naam moes uitbou - die godsdienssin van die sosiale gewete. $\mathrm{Al}$ is die trekkers in die middel van die veld, in groot ongerief, is dit hulle plig om steeds hulle godsdiens te beoefen. Elke aand word godsdiens gehou en elke dag na 'n kerk gesmag waar hulle as Christene tot eer en verheerliking van God se Woord bymekaar kan kom. Die volke in die binneland wat heidense godsdienste beoefen, moet vinnig op die regte weg gewys word en dit word 'n saak van erns by die Afrikaners. ${ }^{55}$

In Die Bou van 'n Nasie word die boodskap van anti-kolonialistiese sterk uitgedra. Dit is die vyandige Britse magte wat die vryheid van die Afrikaner vir hulle eie selfsugtige doeleindes wou kom opeis. As die Afrikaners, in hulle eie oë die sterker volk, vindingryk blyk te wees en vir hulle 'n nuwe tuiste gaan soek, kan die Britse magte dit nie keer nie. Die slimmigheid van die Afrikaner se sosiale gewete word dus hier uitgebeeld. Die Afrikaners stig hulle eie republieke en met die ontdekking van minerale, volgens die Afrikaners deur God aan die Afrikaners geskenk, moet die Britse magte dit ook kom wegneem. Die Anglo-Boereoorlog is ' $n$ traumatiese ervaring in die geskiedenis van die Afrikaners. Afrikaners het hulle soos ware helde gedra en

55 C.C. Nepgen, Die sosiale gewete van die Afrikaanssprekendes (1938), pp. 74-75. 
toe die Britse magte sien hulle sou die stryd verloor, loods hulle 'n oorlog teen die Afrikanervrouens en -kinders. Die Afrikaners moes noodgedwonge die stryd gewonne gee, maar het geweet dat hulle eendag, as God se uitverkore volk, hulle vryheid sou terugwen.

Die Bou van 'n Nasie was 'n nasionalistiese rolprent en dit is gemaak met 'n boodskap om die Afrikaner te bemoedig. Die rolprent is nie bloot verfilm om die Afrikaners te vermaak nie, maar ook om die Afrikaners van 1938 oor hulle geskiedenis op te voed en voor te lig om in die toekoms besluite getrou aan hulle sosiale gewete te neem.

\section{Simon Beyers (1947)}

Simon Beyers sou die eerste Afrikaanse rolprent wees wat internasionaal erken is. Dit was ook die derde rolprent wat deur Pierre de Wet gemaak is. Hy het self die hoofrol saam met Eugenie Heyns vertolk. Die rolprent, hoewel dit baie dramaties is, het vordering in die Afrikaanse rolprentbedryf aangetoon. ${ }^{56}$ In Die Brandwag is oor Simon Beyers geskryf dat dit 'n "dramatiese rolprent uit ons geskiedenis" ${ }^{77}$ is. Simon Beyers is deur die Suid-Afrikaanse Rolprentmaatskappy (SARM) bemark en versprei. SARM, soos dit destyds bekend gestaan het, is deur "vooraanstaande" Afrikaanse persone bestuur - Afrikaners wat die sosiale gewete van die volk beliggaam het. ${ }^{58}$ In Die Brandwag word die volgende oor die bemarking en verspreiding van Simon Beyers gesê:

... tegniese vaardigheid [in ooreenstemming met] die kennis van Afrikaans en die behoeftes van die Afrikaanse publiek, soos hierdie vooraanstaande Afrikaners dit ken. ${ }^{59}$

Simon Beyers is op 'n ware gebeurtenis gegrond. Tydens die sewentiende eeu het Simon van der Stel 50 weesmeisies uit Holland ingevoer om met ongetroude vryburgers aan die Kaap te trou. ${ }^{60}$ Maria (Verna Vels) word so uit Holland gebring om met Simon Beyers in die huwelik te tree. Simon se broer, Nicolaas en sy vrou, Gertruida (Eugenie Heyns) het Simon aangemoedig om te trou, omdat dit volgens hulle die ideaal van

\footnotetext{
56 A. I. le Roux \& L. Fourie, Filmverlede: Geskiedenis van die Suid-Afrikaanse speelfilm (1982), p. 37.

57 Rolprente in Afrikaans, Die Brandwag, 1949-08-08, p.11.

58 A. I. le Roux \& L. Fourie, Filmverlede: Geskiedenis van die Suid-Afrikaanse speelfilm (1982), p. 37.

59 Rolprente in Afrikaans, Die Brandwag, 1949-08-08, p.11.

60 A. I. le Roux \& L. Fourie, Filmverlede: Geskiedenis van die Suid-Afrikaanse speelfilm (1982), p. 37.
} 
elke jong Afrikanerman en -meisie is om getroud te wees en kinders in die lewe te bring. Simon is heimlik verlief op die liewe Gertruida en toe Maria nie aan sy eise voldoen nie, verwerp hy haar en gee al sy aandag aan sy plaas. Simon en Maria sukkel om kinders te hê, maar Nicolaas en Gertruida word met 'n liefste kindjie geseën. Dit maak Simon nog ongelukkiger en jaloers.

Getruida moedig Nicolaas aan om op 'n jagtog te gaan sodat hy 'n bietjie kan ontspan na al die spanning verbonde aan die geboorte van hulle kind. Tydens die jagtog word hy dodelik siek en Maria waag haar lewe om hom in die veld te gaan versorg. Getruida, reeds swak na die geboorte, verswak nog verder. Nicolaas kom gesond terug van die veld af en Gertruida sterf in haar man se arms. Nicolaas, vol haat vir sy kind, vra dat Simon en Maria hom moet aanneem en verlaat die plaas. Simon is verheug dat hy uiteindelik 'n erfgenaam vir hulle familieplaas het en hoewel hy nooit die liefde wat hy teenoor Gertruida gekoester het, teenoor Maria kon bewys nie, aanvaar hy haar bekwaamheid en hulle woon saam op die plaas. ${ }^{61}$

Drie baie prominente ideologieë, onderliggend aan die sosiale gewete van die Arikaner, speel in Simon Beyers 'n rol. Die eerste ideologie is weer eens Afrikanernasionalisme. Baie klem word op die uitbreiding van die Afrikanervolk gelê. Dit is nodig dat die nuwe volk aan die Kaap moet groei tot 'n sterk en magtige volk wat eendag volle beheer oor die hele Suid-Afrika kon uitoefen - die waardigheidsbesef van die Afrikaner. In die rolprent kom tonele voor waar die twee paartjies volkspele doen en met trots Viva la Kompanjie sing. Dit is 'n saak van erns dat alles wat belangrik vir die volk is, ook vir die individue belangrik sal wees. Hierdie simbole vorm deel van die konserwatisme, die behoudenheid van die Afrikaner se sosiale gewete.

Op die plaas is Simon 'n flinke boer. Hy werk elke dag met ywer en erns op sy plaas en neem alles wat met die uitbreiding van sy plaas te doen het, as eerste prioriteit - die sogenaamde landelike realisme van die sosiale gewete. Aan die ander kant is sy broer Nicolaas ' $n$ haan onder die henne en is dit vir hom belangrik om die lewe te geniet. Hy is getroud met 'n beeldskone vrou en volgens Simon geniet hy dit eerder om sy geselskap tussen vroue deur te bring as om op die plaas te help.

Volgens paternalisme is die pater die hoof van die gesin en moet hy die verantwoordelikheid as gesinsleier dra. Die man is die een wat tydens teenspoed sterk moet bly en hy moet sorg dat sy gesin die beginsels en waardes van die volk uitleef. Gevolglik herinner Simon Nicolaas aan sy pligte as man. Simon vervies hom telkens vir Nicolaas omdat hy nie die man is wat Gertruida verdien nie. Die rol van die vrou is dié van ondersteuner, tuisteskepper en opvoeder. Volgens hierdie kriteria

${ }_{61}$ P. de Wet, Simon Beyers (African Film Productions), 1947. 
is Gertruida die perfekte vrou. $\mathrm{Al}$ is sy ook hoe siek, kom die begeertes van haar man bo haar eie versorging. Die veragting wat Simon teenoor Maria koester omdat sy nie aan hom 'n erfgenaam kan besorg nie, verdwyn wanneer hulle na Gertruida se dood Simon se broerskind as hulle eie aanneem.

Verbasterde Calvinisme kom ook in die rolprent na vore. Dit is God se wil dat die nuwe Afrikanervolk in die Kaap gevestig is en dit is hulle plig om Sy wil te gehoorsaam en die volk uit te brei. Dit Bybel verwag ook van die vrou om hierdie funksie te volvoer. Op Maria word as 'n halwe vrou neergesien omdat sy nie aan Simon 'n kind kan gee nie, maar na die aanneming van Gertruida se kindjie word sy tot volwaardige vrou verhef wat met trots deel van die nuwe volk en sy waardes is.

\section{Kom saam vanaand (1949)}

Kom saam vanaand, die eerste vollengte Afrikaanse musiekprent, is in 1949 onder leiding van Pierre de Wet vervaardig. Hy tree in sy hoedanigheid as rolprentvervaardiger op en vertolk nie soos in sy vorige rolprente een van die hoofrolle nie. Hoewel hierdie rolprent langer as Simon Beyers is, word die grootste gedeelte aan tonele van 'n verskeidenheidskonsert gewy.$^{62}$ Hierdie rolprent word nie so sterk deur ideologieë oorheers nie, maar blyk eerder bloot tot die vermaak van die gehoor te wees.

Kom saam vanaand handel oor ' $n$ talentvolle Afrikanermeisie wat op die vooraand van die verwesenliking van haar groot drome deur 'n fratsongeluk verlam word. Net ' $n$ gespesialiseerde rugoperasie wat slegs in die Verenigde State van Amerika uitgevoer kan word, sal aan die meisietjie 'n beter toekoms kan gee. Omdat dit voor die ongeluk finansieel nie goed met die gesin gegaan het nie, verkeer die gesin na die ongeluk nog steeds onder groot druk om vir hulle twee dogters 'n toekoms te kan skep. Die oudste suster se kêrel, 'n goed gemanierde jong man, besluit om met Pierre de Wet (deur homself gespeel) te gaan gesels en te hoor of 'n oplossing vir die gesin se probleme gevind kan word. ${ }^{63}$

De Wet stel dan vindingryk (Nepgen se slimmigheid) voor dat hulle 'n konsert reël en dat al die fondse wat tydens die konsert ingesamel word, aangewend word om die koste van die operasie te help dra. Die Brandwag skryf in 1949 in 'n resensie oor die rolprent die volgende:

'n Kenmerk van die film is dat die bekende Afrikaanse kunstenaars wat vir die konsert verantwoordelik is, onder hulle eie name optree - slegs die persone wat die verhaal dra, het denkbeeldige name. So kry die skouburgganger met

62 "Kom saam vanaand": Eerste musiekprent in Afrikaans, Die Brandwag, 1949-09-02, p. 8.

63 P. de Wet, Kom saam vanaand (African Film Productions), 1949. 
van ons bekendste kunstenaars in lewende lywe te doen: Hendrik Susan en sy orkes, Betsy de la Porte, Dirk Lourens, Al Debbo, Trudi van Zyl, Frederik Burgers... ${ }^{64}$

Aan die einde van die rolprent word die goeie nuus aan die gesin oorgedra dat hulle wel nou hulle dogter vir haar rugoperasie kan neem. 'n Blink toekoms ontplooi vir die dogter ${ }^{65}$ Hoewel Kom saam vanaand openlik daarop gemik was om te vermaak, kan twee ideologieë onderliggend aan die sosiale gewete van die Afrikaner, daarin waargeneem word.

Die tema van Kom saam vanaand is regdeur op naasteliefde gegrond en hoe die Afrikanervolk moet saamstaan en mekaar deur moeilike tye moet ondersteun. Afrikanernasionalisme vorm die agtergrond vir hierdie rolprent. In die rolprent word 'n gevoel van kameradie geskep. 'n Afrikanermeisie, heeltemal onbekend en vir die vermaaklikheidswêreld in daardie spesifieke stadium van geen waarde nie, word dadelik deur 'n hele volk ondersteun omdat die lewe haar so vroeg van haar drome ontneem het. In teenstelling met die buiteland, is Afrikaanse rolprentsterre se harte oop om aan hulle naaste hulp te verleen. Kunstenaars het gratis aan die konsert deelgeneem, met die gevolg dat die kaartjieverkope genoeg was om vir die operasie te betaal. Net Afrikaanse kunstenaars is gevra om aan die konsert deel te neem. Eg Afrikaanse items is gelewer, asook 'n demonstrasie van volkspele met tradisionele Afrikaanse liedere.

In die rolprent word ook baie subtiel op die ideologie van verbasterde Calvinisme gesinspeel. As jy 'n goeie Christen is en 'n meisie help wat in nood verkeer, is jy by implikasie ook 'n goeie Afrikaner - 'n Christen-Afrikaner. Dit sluit by die godsdienssin van die Afrikaner se sosiale gewete aan. Die ongeluk word as die "wil van God" beskou en die Afrikaner moet hierdeur leer dat selfs 'n ongeluk hulle kan laat saamstaan.

\section{Slot}

Die ideologieë van veral Afrikanernasionalisme, verbasterde Calvinisme en paternalisme, onderliggend aan die sosiale gewete van die Afrikaner, en die sosiale gewete-eienskappe van godsdienssin, waardigheidsbesef, slimmigheid, konserwatisme en landelike realisme het die sterkste in die drie bespreekte rolprente voorgekom. Die rolprente het visuele beelde aan die Afrikaners oorgedra van die wyse waarop Afrikaners behoort op te tree wanneer hulle met lewenskrisisse gekonfronteer word.

\footnotetext{
64 "Kom saam vanaand": Eerste musiekprent in Afrikaans, Die Brandwag, 1949-09-02, p. 8.

65 P. de Wet, Kom saam vanaand (African Film Productions), 1949.
} 
Dit was nie net goeie vermaak vir die volk nie, maar het ook as riglyne gedien om 'n aanvaarbare lewenstyl aan die volk te openbaar, die sogenaamde sosiale en rigtinggewende gewete van die Afrikaner.

Die waarde van so 'n studie is dat dit 'n mens, binne die huidige tydgees van besinning en nostalgie oor kultuurskatte, met empatie en begrip vir die kultuurskeppinge van weleer vervul. Dit open 'n mens se oë vir die optrede van Afrikaners wat volkswaardes en norme geskep en dit aan mede-Afrikaners voorgehou het. Die toedrag van sake sou in die vyftiger- en sestigerjare van die twintigste eeu in intensiteit toeneem. 